\title{
Chapter 12 \\ Recent Evolutions of Gender, State Feminism and Care Models in Latin America and Europe
}

\author{
Julie Jarty and Karina Batthyány
}

\begin{abstract}
This chapter presents and characterises the way in which, in the twentyfirst century, after years of feminist struggles inside and outside of institutions, gender relations are organised in the different countries of the INCASI project (on the European side, Spain, Italy, Finland, France and the United Kingdom, on the side of the South American Southern Cone, Argentina, Brazil, Chile and Uruguay). It pays special attention to the implementation of feminist issues on political agendas, and in particular the assignment of women to unpaid care work - an aspect of the power continuum that we look to relate to other aspects. Gradually and for almost a century all countries in both continents have granted women the status of subjects, citizens and employees. However, the conditions, challenges and timelines of this process differ considerably from one continent to another, so they need to be addressed separately. The neoliberal era did not have the same impact in Europe as it did in South America (nor was it exactly the same between particular European countries or among South American ones).
\end{abstract}

Keywords Gender $\cdot$ State feminism $\cdot$ Care work · International comparison

\subsection{Introduction}

In a worldwide context of social crisis of capitalism (Fraser 2013), big questions are arising on both sides of the Atlantic and the equator: on the one hand, was the expansion of the Welfare State in Europe, commonly viewed as favourable to access

\footnotetext{
J. Jarty $(\bowtie)$

Centre d'Etude et de Recherche Travail Organisation Pouvoir, Toulouse Jean Jaurès

University, Toulouse, France

e-mail: jarty@univ-tlse2.fr

K. Batthyány

Departamento de Sociología, Universidad de la República, Montevideo, Uruguay
}

(C) The Author(s) 2021 
by women to social citizenship, interrupted by the 2008 financial crisis and the subsequent austerity policies? On the other hand, did the fragility of the 'turn to the left' (the 'Pink Tide') in South America only lead to a marginal stabilisation of state feminism that could specifically and sustainably improve the everyday lives of women?

We take note of the feminist criticisms of the Welfare States that came about in the 1990s (Pateman 1988; Lewis 1992; Orloff 1996). This chapter shows how gender is a relevant category of analysis in order to understand social welfare systems and the way they have evolved in the neoliberal era. In the face of the mainstream of "androcentric and falsely universalizing" comparative approaches (Orloff 2009), we reveal the economic and social contribution by women in the era of financial capitalism and the subsequent disruption of social (and family) solidarity. The idea is therefore to understand how the nine Welfare States in the INCASI project countries are working (or not) to recognise this contribution and potentially transform it towards more gender equality. In doing so, the aim of this chapter is to contribute to a better understanding of how gender continues to influence and shape modern social welfare systems, and, in turn, how the intensification of neoliberal policies is transforming gender relations and feminist concerns. To do so, we recur here to European and contemporary feminist literature, in order to put these matters into perspective.

Considering each of the nine INCASI countries, this chapter is structured into three parts: the first traces the emergence of women's rights and state feminism in the different European and Latin American countries studied; the second reexamines the gender 'contracts' or 'regimes' resulting from the degree of 'defamilialisation' and social organisation of care, i.e. the state measures adopted (or not) to free women from the domestic and family duties that are still a female prerogative. The third part looks at the consequences for gender in contexts of crisis and conservative decline (austerity and right-wing populism, among others), in order to better understand contemporary gender issues.

\subsection{State Feminism}

The 1990s brought a milestone for the institutionalisation of feminism both in Europe and in South America. The defence of women's interests (viewed as a social category) was granted the status of a major political issue in certain public and especially international institutions. On the back of the UN's recommendation in 1975, the European Union (EU) adopted specific structures and ordered its Member States to adapt their legislation to the imperative of gender equality-an imperative that was highly focused on the economic goal of increasing the participation of women in formal, salaried labour. Later, the preparations for the World Conference on Women in Beijing (1995), at which European feminists were highly active and where 'gender mainstreaming' was formalised, had a direct impact on the 'global south'

This 'state feminism', though variable between countries, was characterised, first, by the creation of specialised public departments and then by the setting of quotas to facilitate access by women to positions of power. In addition to this 
state-centric turn in feminism, there was also a major process of 'NGO-ization' (Mendoza 2014), which involved state collaboration with militant NGOs with support from international donors. And on both sides of the Atlantic, feminist movements integrated international institutions to intervene as promoters or supervisors of new policies to reduce gender inequalities.

However, state feminism did not lead to full adherence of the feminist movement. Nor did it lead to the same dynamics, nor to the exact same consequences in the two studied continents. And its degree of implementation in different countries says something about the state of gender relations, in particular, in relation to the analysis of state regulation of care.

\subsubsection{Woman-Friendliness of (EU) Institutions after the Second Feminist Wave: Truths and Myths}

In the industrialised countries of the north, the second half of the twentieth century is often presented as a historic moment for feminism, known as the 'second wave'. In parallel to the transformation of the labour market and the advent of paid labour as the dominant form of employment, women took to the streets demanding access to political, social and economic citizenship. They were established in and outside of institutions and contributed to major legislative advances, cleansing legal systems of their most discriminatory characteristics and formally guaranteeing freedom and autonomy of women as citizens in every right. The regulation of divorce ${ }^{1}$ and the right to abortion ${ }^{2}$, perceived as necessary requirements for any emancipatory life project, were symbols of the gradual incorporation of gender relations in democratic law.

Of the five European countries studied, only Spain, strangled by General Franco's dictatorship until 1975, would not witness this second feminist wave until later ${ }^{3}$. This dark side of Spain's recent history probably partly explains why the institutionalisation of feminism generated less scepticism within the women's movement than in other countries (Lombardo 2017). For another reason, the Nordic countries of Europe, such as Finland, also developed a positive view of state feminism, which allowed them to achieve a high level of gender equality through the state. In contrast, Italian, French and British feminist movements were more critical of state feminism, emphasising the risks of appropriation and de-politicisation of feminist

\footnotetext{
${ }^{1}$ In 1969 in the United Kingdom, in 1970 in Italy, in 1975 in France and in 1981 in Spain.

${ }^{2}$ In 1967 in the United Kingdom, 1969 in Finland, 1975 in France, 1978 in Italy and 2010 in Spain respectively.

${ }^{3}$ Two other southern European countries were under military dictatorships that delayed the transition to modernity and the changes that revolutionised the role of women in society: in Portugal, the long Salazar dictatorship (1926-1974) and in Greece, the so-called Regime of the Colonels (1967-1973).
} 
issues, and the co-optation of other interests such as the defence of the liberal economic model.

The European Union played a central role in the institutionalisation of feminism, beginning in the 1960s and 1970s. Progressively encouraged by international recommendations in favour of women, European states explicitly appealed to feminists to reform the law and institutions. The 1995 Beijing World Conference was a turning point for putting feminist issues on the international agenda, particularly with respect to the application of gender mainstreaming. It should be noted, however, that in most countries, historically left-wing governments were the most receptive to this call and are the ones that offer most windows of opportunity in this regard. In Spain, the return to democracy and a left-wing government from 1982 led to the inclusion of feminist issues on the political agenda: the Instituto de la Mujer (Women's Institute) was created in 1984. It would not be until the left returned to power, twenty years later, that the Secretaría General para la Igualdad (General Secretariat for Equality) was created, which became a ministry in 2008. Similarly, in Italy, the centre-left governments of the 1980s and 1990s were the only ones to suggest a more favourable context for the institutionalisation of feminism, despite the fact that the country was struggling to recover from the backlash that followed the women's movements of the 1970s (Faludi 1991). Successive equal opportunity ministers, Finocchiaro, Balbo and Belillo of the Prodi, Alema II and Amato II governments, for example, re-established relations with the feminist movement and opened opportunities for feminist activists to enter the institutional scene (Lombardo and Sangiuliano 2009). On the contrary, the arrival of model and show girl Carfagna in the same ministry in 2008, a member of Berlusconi's liberal and conservative government, marked a new break from the militant base (Lombardo and Del Giorgio 2013). In France, since the creation of the Secrétaire d'État à la Condition Féminine in 1974, all governments had a ministerial position dedicated to women's rightsalthough not always an entire ministry. The State also created central and decentralised services specifically for women, and is developing a public action to promote gender equality (Dauphin 2010). In Finland, social democracy and the advanced development of the Welfare State that is so typical of Nordic countries favoured state feminism, promoting a shift from an equality in right to a de facto equality.

\subsubsection{State Feminism under (UN International) Control in Latin America}

Due to the omnipresence of dominantly colonial relations even in the production of knowledge (Hill Collins 1990, 2000), the notion of the 'second feminist wave' that sparked state feminism, is falsely universal. This 'wave' did not echo the same way in Latin America and particularly in South America. Moreover, state feminism is poorly documented in South America, as noted by Magalhaes and San Romanelli (2017). In fact, it is not at all easy to comprehend the processes by which feminism 
has been institutionalised in Latin American countries, and especially in comparison with Europe.

It is important to note that, at a time when most European countries are entering a democratisation phase in terms of gender relations, the four countries studied here all sank into military dictatorships at the same time. These dictatorships prevented militant expressions and sustainably changed the priorities and goals of the feminist cause $^{4}$. Of course, although women had acquired certain rights before the military coups, the position of feminist issues on political agendas is closely linked to the specific context of the end of those military dictatorships (1983 in Argentina, 1985 in Brazil and Uruguay, 1990 in Chile). The arrival of the new democracies created a particularly favourable context for the politicisation of gender issues, helping both to put feminist opinions on the national political agenda and, on a more institutional level, possible recommendations and partnerships with the UN and its specific agencies such as UNIFEM and ECLAC. This phenomenon was particularly characterised by the specific work of feminists within NGOs, study centres, university spaces, and national and transnational networks, and which played a role in raising awareness and monitoring of state institutions and affairs.

This progressive institutionalisation of gender issues would lead, in three of the four studied countries, to the election of women to the highest state positions during the so-called 'Pink Tide': Chilean Michelle Bachelet in 2006 and again in 2014, Argentinian Cristina Fernández de Kirschner in 2007 and Brazilian Dilma Rousseff in 2010 (re-elected in 2014 until the coup d'etat of 2016). On the contrary, it should be noted that in the European countries that are part of the INCASI project, only Finland and the United Kingdom have had women occupy this symbolic position, respectively with the election of Democrat Tarja Halonen in 2000 and 2006 and (more atypically because they are ultraconservative and liberal) Margaret Thatcher in 1975 and Theresa May in 2016. Although this way of affirming the voice and presence of women in the public sphere is not, as such, a guarantee of state feminism, it is derived very directly from it: for the British sociologist Sylvia Walby, it is an indicator (among others) of democracy (Walby 2009). On a less emblematic level, the South American state-centric turn was characterised by the integration of feminist women in institutional arenas, whether national or international. This phenomenon in relation to the state-centric turn is still highly controversial in feminist thinking. It generated a flourishing of feminist scientific production on the part of Latin intellectuals, with their critical and decolonial tradition. So, following on from Aníbal Quijano, author of the notion of 'coloniality of power', Breny Mendoza introduced the notion of 'coloniality of democracy' (Manrique 2019) which is reflected in the absence of poor women, and of women from traditions linked to native, Afro or mestizo peoples, with little access to formal education and health. Marielle Franco, the "black feminist woman and daughter of the favela" as she defined herself, city councillor in Rio de Janeiro, Brazil, was a symbol of the

\footnotetext{
${ }^{4}$ Fights against social inequalities and poverty, but also calling for an account of the prisoners who disappeared during the dictatorship (the Plaza de Mayo campaign by mothers in Argentina, for example) were a huge specific feminist challenge.
} 
possible transformation of state feminism and its opening up to minorities. In turn, her assassination can be viewed as a brutal backlash, a symbol of violence and the appropriation of power by the dominant groups.

The first demands of state feminism were partly similar to those of the second feminist wave in Europe, revolving around the issues of politicisation of private life, in particular: (1) criticism of the assignment of domestic and care work to single women, (2) demands for reproductive and sexual rights, and (3) the fight against gender violence, following on from the goals of the Beijing conference. However, even more than in the European countries studied here, these matters have yet to be fully applied to politics. First of all, in terms of reproductive rights, only Uruguay achieved the decriminalisation of medical abortion in 2012, while all the European countries have legalised it ${ }^{5}$. Similarly, the institution of marriage is still limited to same-sex couples in Brazil (where there is, however, an alternative form of civil union) and in Chile - this is also the case in Italy (Spain, Finland, France and the UK have recognised same-sex marriage, although at different times and not without heated debate). Secondly, the gender gap in the distribution of productive and reproductive work between men and women is another complex issue because it depends so largely on the consolidation of the Welfare State and its social protection systems, key components of idealised state feminism (following the example of the Nordic countries). And in this respect, the academic literature is often sceptical about the very use of the notion of the Welfare State in application to Latin America (Martínez Franzoni 2008). Of the four INCASI countries, only Argentina and Uruguay have intensified their social welfare systems.

Finally, in both continents, state feminism is established in a context of a deteriorating labour market with extremely tangible consequences for women: plans for economic emancipation through paid employment are being implemented at a time when women are realising that they will never experience the same benefits of employment that men may have done during the period when capitalism was expanding (Le Feuvre 2018). The issue of job insecurity (especially in Europe) and poverty (especially in Latin America) will become central concerns for state feminists, especially with regard to the following interrelated phenomena: the increase in the number of divorces and separations and, therefore, women at the head of single-parent families; the increase in the number of women working for a salary outside the home; the maintenance of the sexual divide in terms of unpaid work at the expense of women; the emergence of a childcare crisis; and the 'birth strike'. The possibility of a Social State means we can expect women's social welfare, living and working conditions to improve. However, reforms to social protection systems and the consideration of gender as a structuring principle thereof will not

\footnotetext{
${ }^{5}$ Access to abortion rights in the European INCASI countries should not hide the fragility of this legacy (for example, it was directly questioned in Spain in 2014), the discrepancies between the law and its application (in southern Italy, for example, it is almost impossible to get an abortion) and regional disparities (in France, long waiting lists do not allow all women to get an abortion within legal deadlines).
} 
occur in the same way in countries with very different political traditions and social emergencies.

\subsection{Gender and Welfare State Systems}

Despite the shared legacy of the Male Breadwinner/Female Carer model and the widespread appearance of the Adult Worker (or Dual Earner) model, all countries are organised on the basis of very different principles, as well as very different national architectures in terms of gender equality. Within the diversity of countries of the European Union and Latin America in the INCASI project, we can identify very different 'gender regimes'. So, our comparison could easily fall into the trap of what Oinonen and Tervonen-Gonçalves (2019) identified as a North-South dichotomy: on the one hand, the 'modern/advanced/superior students' (such as Finland, one of the so-called 'women friendly' Nordic states), and on the other hand, the 'bad students' (such as Italy and Spain, whose structures have traditionally been regarded as more patriarchally rooted). Adding Latin American countries (Argentina, Brazil, Chile and Uruguay) to our comparison could further intensify the risk of enclosing countries in biased, hierarchical classifications, since their transformation of gender issues into policy does not follow the same agenda as the European Union. Due to these very different reputations emanating from the dominant discourses, we prefer to use comparison to show the complexity, in a neoliberal context, of the transition from the Male Breadwinner/Female Carer model to the Adult Worker one.

\subsubsection{Variations and Trends in European Union Care Regimes}

Finland has a social democratic model with a typically Scandinavian universalist welfare state, associated with generous social benefits (for example, in terms of public childcare services, paid parental leave and care rights) and a system of high taxes (Korpi 2000). It has a strong tradition of state feminism, as it is part of the (controversial) 'Nordic Nirvana' myth in terms of equality. The country developed universal childcare services from the 1960s and 1970s, as well as a culture of 'state motherhood' that greatly supports the full-time employment of women (PfauEffinger 2004). Passed in 1973, the Childcare Act regulates the care of young children and provides programmes outside the education system for children under 7 years of age. Its 1985 reform was accompanied by a subsidy for homecare by parents. The Childcare Act was strengthened in 1996 when the right to municipal care services became a legal right for all children. Due to these extensive national policies, the impact of the European Union has been limited in most cases. However, Finland's 'women friendly' Welfare State has always been weaker than those of 
other Scandinavian countries (such as its neighbour Sweden). So-called 'cash for care' policies in the 1990s were mainly aimed at mothers and not towards fathers. Also, compared to other Nordic countries, Finnish fathers are near the bottom of the list of users of parental leave: parental leave is 158 working days, of which 105 are used by the mothers. So, while Sweden is closer to the so-called 'universal caregiver' model identified by Fraser (1997), Finland is more in line with the so-called 'caregiver parity model', in which women are paid (albeit a low percentage) to take care of young children. In fact, in the 1990s, women's employment rates decreased, but they were always higher than in the other countries studied.

Also with a high degree of acceptance of state 'interference' in the private and commercial spheres, France occupies an intermediate position. In comparison to many European countries, it presents greater evidence of institutional policies for family welfare, with significant consequences (often viewed as paradoxical) in terms of women's participation in the labour market and fertility rates, both of which have long been the highest in the EU (Fagnani 2007). Although it is often described by specialists as a country divided between feminism and familialism (Jarty 2006), French social policies always oscillate between aid provided to working parents and caregivers (without formal gender distinction) and others aimed at mothers. So, on the one hand, in addition to free, full-time school available to all children from the age of three, since the 1980s there has also been funding and construction of collective public nurseries to extend school hours (morning, afternoon and evening) to cover the care of these children. On the other hand, the conditions for access to and payment of parental leave have encouraged exclusion of fathers from this right, and hence a widening of the gender divide. These measures explain both the full-time employment rate of French women, historically very high, and the professional and social instability of less privileged mothers. In line with this contradiction, Lewis (1992) identified France as a Modified Male Breadwinner model in which caregiving (of children and, more generally, of dependent persons) is not shared between women and men, but among women (of the middle and upper social classes), and also the state (Jarty 2006).

Italy and Spain share similar sociocultural characteristics, among others Catholicism, familialism and a strong patriarchal culture, a consequence of which has been their historical connection with the Mediterranean welfare subset (with Greece and Portugal). Strong family ties and the late decline of the Male Breadwinner model characterise, among other things, the social models of these southern European countries. The sexist nature of their family employment systems has also explained their fertility rates, which are among the lowest in the European Union. Associated to the lack of family policies and, above all, to the low levels of public childcare services, the phenomenon (sometimes interpreted as a 'birth strike' (Crompton 1999a, b)) was intensified after the Great Recession in Europe: 1.32 children born to women in Italy and 1.31 in Spain in 2017. However, in the first decade of the twenty-first century, the comparative panorama between Italy and Spain is quite different. The 'silent revolution' that transformed the employment, education and family of women (Goldin 2006) was more radical in Spain. Although 'the family' is considered by convention to be a 'private' sphere, the Spanish Welfare 
State began offering some policies that were positive for families and supported the idea that gender issues, which were previously defined as personal, are actually highly political. So, in the 2000s, there was a remarkable change in Spain, such as the extension of the three pillars of education, health and pensions to a 'fourth pillar of welfare' that included family and social services (Navarro 2004). In consequence, from the mid-2000s, the proportion of Spanish women in the labour market has grown considerably and the idea that the woman's place is in the home has faded even more. On the contrary, Italy has continued with its more traditional views of gender and motherhood, and women are still on the periphery of the labour market. According to OECD data, while $78 \%$ of women aged 24 to 54 were in the labour market in Spain in 2010, only 64\% in Italy were, one of the lowest female employment rates in the European Union. Despite the rise of the Adult Worker Model in the European Union (promoted by the European Employment Strategy) and the female drive for emancipation, as well as the need for families to survive on two incomes, Italy is still typically resistant to depart from the family welfare model. Women continue to provide most of the care and assistance to dependent family members (especially in the southern regions of the country), and this is even more the case since the economic recession. Being so strongly affected by drastic budget cuts (particularly towards local governments responsible for social services) and by the dismantling of what were already only embryonic social policies, Italian women are likely to replace the State (Segnana and Vila 2015). For example, when it comes to childcare services for children under 3 years of age, the average coverage rate was around $13.5 \%$ in 2014 in Italy, well below the Barcelona Target of 33\% for 2010. Some research has identified a 'new intergenerational solidarity trap' for young Italian women: the family versus employment (Segnana and Vila 2015).

The United Kingdom has been classed as a 'liberal' Welfare State: the structure of its labour market (characterised by flexible deregulated employment, and long working days for men, the longest in the EU) and its welfare policies (characterised by the absence of generous provisions for the family) take it closer to the United States welfare model than the rest of Europe (Crompton 2006). In consequence, and because it is the most accessible way to achieve a balance between working life and private life, a high proportion of women have entered the UK labour market on a part-time basis. This phenomenon demonstrates the real relevance of what Crompton (2006) identifies as the 'one-and-a-half earner model', according to which the man works full-time and the woman part-time, the most frequent (heterosexual) domestic arrangement in the United Kingdom. However, belonging to the European Union has been very significant for working life and family-friendly policies: a series of policy improvements were adopted to bring the United Kingdom in line with European Union regulations.

Although the United Kingdom and southern European countries such as Italy and Spain do not belong to the same category in the Esping-Andersen classifications and their feminist critics, or to the social models presented in the second chapter, they share more similarities in terms of state support for care. All three were lagging in recognition of the importance of childcare services. Even before the crisis, there was evidence of a convergence in the commitment and potential of women in Spain 
to even go ahead of women in the United Kingdom due to their continued preference for full-time work and making an even more critical contribution to family budgets. The new laws even recognised social support rights for older people who live with their children and who were traditionally expected to receive family care (Sarasa 2011). Both countries have expanded the offer of childcare services, with greater coverage in Spain than that registered in the United Kingdom. This meant a major increase in jobs in the public sector for women: in Spain, this sector accounted for a quarter of the growth of four fifths in total female employment. In the United Kingdom, overall growth was slower (11.4\%), but public services accounted for the majority $(10.5 \%)$. Despite the higher growth rate, the concentration of women in public service jobs in Spain is still only 38\%, compared to $49 \%$ in the United Kingdom (Rubery and Karamessini 2013). Once again, forecasts of the impact of cuts in planned and existing services on female employment are ambiguous, as in both countries women had entered employment before support for care was generalised. However, austerity policies can be expected to increase the total workload of women and limit their ability to access or remain in paid employment.

Traditionally, women either remained in full-time work or left and took up informal work (Torns et al. 2013), but post-childbirth abandonment has been declining in Spain (Salido Cortés 2011). In addition, in Spain, despite the growth in part-time work, part-time employment rates among mothers of young children are only slightly higher than those of child-less mothers, while in the United Kingdom the employment rates of mothers are approximately five times higher (Rubery and Karamessini 2013).

In line with Mediterranean countries, those of Latin America share a high level of commitment among women to childcare and inter-generational financial support. However, South American countries are no longer monolithic and national peculiarities are strong. Machismo, the different forms of paternalism and maternalism, and also social efforts supported by feminists (inside and outside of the state) are expressed differently.

\subsubsection{Variations and Trends in Latin American Care Regimes}

In Latin America, and in the four countries studied in the south of the continent, in comparison to Europe, the sexual division of labour and balance between professional and family life were not priority issues of the feminist movement, nor of unions. However, in the face of the challenges posed by new gender dynamics and their social, economic and demographic consequences, and albeit slowly, many Latin American countries have made legal and regulatory changes in relation to care benefits. As in European countries, Argentina, Brazil, Chile and Uruguay face the so-called 'care crisis', a symptom of the increasing participation of women in the productive sphere, outside of the home, both for financial emancipation and/or for vital needs. Latin American women have been participating more and more in the labour market since the 1990s, often with a higher level of education than their male 
counterparts, but against a backdrop of tremendous socio-economic inequalities that are highly specific to South America. The disproportionate amount of time that women work in comparison to men, as well as the lack of possibilities for caring for children, the sick and the elderly, led governments to consider actions in this territorial area and to seek new forms and models for development (Batthyány 2015; Blofield and Martínez Franzoni 2015).

At the most recent regional meetings (in Santo Domingo in 2013; Brasilia in 2010; and Quito in 2007), Argentina, Brazil, Chile and Uruguay highlighted the need for care to be treated as a central concern. But there are two coexisting political views on the matter: one that sees care as a right and another that sees it as a 'women's problem' that the state, companies or the third sector can support (or not). This latter scenario, called 'familiar' (Aguirre 2008) is the predominant one in Latin American countries (including those in the Southern Cone). In other words, the main responsibility for welfare lies with families and women in kinship networks.

In comparison to Europe, the reality is more complex in countries with typically huge social divides that got wider in the late twentieth century. While there are several South American adaptations of the classifications of social welfare, in particular the one established by Esping-Andersen (Filgueira 1998), the contributions of its feminist critics resonated very little in Latin America. In other words, the South American feminist literature has not really made the same kind of effort to classify countries according to how close or distant they are to the male breadwinner/female carer model. Consequently, Argentina, Brazil, Chile and Uruguay cannot be presented in the same way as we have just done for Spain, Finland, France, the UK and Italy. However, the comparative analyses conducted by Costa Rican feminist sociologist Juliana Martínez Franzon (2008a, 2008b) on the welfare models that slowly emerged in South America do enable some parallels with European feminist classifications. Inspired by feminist researchers in the north (like Diane Sainsbury, Ann Shola Orloff and Jane Lewis), Martínez Franzoni questions social policies that promote flexitime, paternity leave and childcare. These reflections led to the construction of a typology of Work-Family Policies, built around three criteria to assess their quality (Blofield and Martínez Franzoni 2015). The first two criteria are based on the potential to promote the 'gender equity' of social policies, which are divided according to their views of what gender equality is: on the one hand, 'maternalistic' measures that are aimed almost exclusively at mothers and that, in the tradition of difference feminism, reinforce the idea that care is the sole responsibility of women. On the other hand, 'co-responsibility' measures that, from a perspective of gender change, are aimed at both fathers and mothers and that seek the implication of both states and men in care. The third and last criterion is linked to the goal of 'social equity', i.e. considering accessibility of care services to everyone. This criterion was established in coherence with the general shift towards liberalisation and privatisation of care services, a phenomenon that has very special consequences in countries with high income inequality such as those in South America. Here, social welfare through paid employment generates significant divides (gender, class and racial, among others) because informal employment is still so widespread and 
especially affects women, migrants or colonised groups ${ }^{6}$. This is because not only do poor women participate less in the paid labour market, but when they do, they get less labour-based benefits than richer women, most of all because they have to work of their own account or in unprotected occupations such as paid domestic jobs. Therefore, this trend is exacerbated in single-parent households, where women bear the burden of breadwinning and care alone. This latter criterion of 'social equity' is a question of considering these social processes of specific exclusion that are so widespread in the Latin American continent (and increasingly more so in Europe since 2008), which impact the way that the specific effects of gender policies are analysed. For example, the absence of paternity leave, an iconic core goal of European state feminism, cannot really be interpreted in the same way in Latin America:

\begin{abstract}
An extension of paternity leave for salaried workers in any European country will have more progressive distributive implications along socio-economic lines than an extension of paternity leave for salaried workers in any Latin American country. By the same token, an extension of maternity leave to non-salaried workers in Latin America will have a more progressive distributive implication along socio-economic lines than the same leave in Europ (Blofield and Martínez Franzoni 2015: 16).
\end{abstract}

Finally, Martínez Franzoni's study can be used to highlight a kind of continuum from Chile, with its liberal and strongly maternalist/patriarchal orientation, at one extreme, to Uruguay, with its more gender friendly protectionist-state orientation on the other. Between the two is Brazil, the most unequal continent-country in the world, with its maternalistic position in a protectionist state; and Argentina, with its liberal and maternalistic orientation but also with a social welfare regime.

Presented as the laboratory of neoliberalism since the coup d'état of Augusto Pinochet in 1973 and its legacy of the 'Chicago Boys', Chile set up (and then preserved) an ultra-minimal social welfare system that only provides a flimsy safety net for the poorest populations. State intervention is limited mainly to the economic sphere: it has quickly shifted from state provision of services to privately provided services, in particular regarding health, education and pensions. Chile therefore has a liberal single-supplier or market-based welfare regime (Sunkel 2007). In addition to ultra-liberalism, there is also familialism, which leads to the persistence of a rigid sexual division of domestic work. This country's female employment rates are among the lowest in Latin America, particularly with regard to women from lowincome households. Social services were totally privatised in the 1980s, and the social-liberal changes of socialist Michelle Bachelet did little to erode those foundations. With 24 weeks of maternity leave for all working mothers in the formal sector (representing only 55\% of working women in 2008, and only for those in the highest incomes brackets), Chile is above the South American standard of 14 weeks (ILO standard) (Blofield and Martínez Franzoni 2015). The policies and programmes to balance family and working life are poorly developed, apart from

\footnotetext{
${ }^{6}$ For example, women from popular sectors who often work informally cannot access maternity leave.
} 
maternity leave policies for working mothers, where Chile is at the forefront. The Chile Crece Contigo (Chile grows with you) programme is considered the main care policy in this country, but by virtue of a new postnatal law passed in 2011, mothers can transfer up to a month and a half of leave to fathers. This institutionalisation of shared parental leave made Chile one of the first countries in the region to begin what is still an embryonic phase of redirecting efforts towards the inclusion of fathers in the debate (with Cuba and Uruguay in 2013).

In Brazil, the feminist problem regarding care for dependent persons has been institutionalised in accordance with two different gender logics. The first is maternalistic and is aimed at women as mothers and connected to poverty relief programmes (for example, the Family Subsidy Programme). The second, focused on developing early childhood policies, refers to mothers as workers (Sorj and Fontes 2009). As in Chile, Brazil's maternalistic orientation is reflected in a long-term maternity leave (almost 17 weeks) for all mothers working in the formal sector. The poverty of working mothers in the informal or precarious sector led, in the 1990s, and as in other South American countries, to the development of policies to combat poverty and specifically maternal poverty, and which make women privileged intermediaries in the relationship established between the state and families, placing them at the centre of the system. Such a phenomenon, which comes from the observation whereby women, unlike men, tend to focus their income on family expenses, had consequences in terms of the maternalistic orientation of Brazilian family policy: it encourages the priority assignation of women to domestic work and care that is done for free. Therefore, the resolution of the empowerment of poor working mothers was never based on promoting the distribution of domestic and care work and participation of men.

Along with this maternalistic tradition, and as a continuation of a quest to promote social equality, Brazil is also characterised by its (laborious) effort to apply a universal right. Under pressure from a feminist movement that has focused on this issue since the 1970s, nurseries for children under 3 years of age were established as a universal right in the 1988 Constitution, and efforts since then have focused on making this right a reality. Between 1996 and 2006, the number of children under 3 years of age in nurseries rose from $7.4 \%$ to $15.5 \%$. For the next group, children aged 3 to 6 , the rate rose from $53.8 \%$ to $76 \%$, an increase of more than $20 \%$. But class divides are noted: in 2006 , only $9.9 \%$ of children under 3 years of age and from poor families were in nurseries (Sorj and Fontes 2009).

Argentina was considered a ground-breaking Latin American country in the development of its social welfare system, but from gender mainstreaming 'political maternalism' institutionalised the assignation of women to the care of children, the sick and dependent persons (Nari 2004). Across crises and economic adjustment policies, Argentinian women became a fundamental support for household welfare by attending to (as workers) the provision of (meagre) income and attending to (as caregivers) reproductive activities. Hence, in Argentina, the "social and political organisation of care" (Faur 2014) evolved in accordance with the crisis and the moments of economic recovery. The neoliberal policies of the 1990s generated a series of structural reforms that privatised many of the basic social services, such as 
education, healthcare and social security. Short-term programmes focused on the most at-risk groups, groups in which women are increasingly more represented. The major crisis of 2001 plunged the country into a situation for several years in which the vast majority of families had to find new strategies and methods to ensure a minimum level of welfare. In the post-crisis period, certain aspects of social welfare were modified: the Néstor Kirchner and Cristina Fernández administrations led to the reactivation of the state's welfare function through the adoption of social policies that protected (i) workers and (ii) the poorest households with children.

Eleonor Faur identifies in Argentina four alternatives for social welfare applied to care, especially of children (Faur 2014). These alternatives are closely related to the economic situation of households, and would probably also reflect the other countries in the region:

- Mothers as full-time caregivers prolong the traditional central role of women as the carers of children and dependent persons, but this is also explained by an economic rationality in the popular sectors (because it means there is no need to pay somebody else to provide that care).

- Care provided by other family members is based on solidarity or, in contexts of poverty, on the compensation produced by a 'care microeconomy' and 'new social welfare' within the community.

- Access to public services holds increasing value following the laws that recognise the rights of children to access educational institutions after 45 days $^{7}$, but the offer is highly imbalanced and fragmented, characterised by a shortage of free, public provision.

- The commodification of care concerns 3 out of 10 Argentinian children whose families have sufficient resources to pay for private nurseries (managed by churches or secular organisations) and domestic services (of differing quality depending on the price).

Unlike its neighbours, Uruguay is the only country that was not completely submerged in post-dictatorship-neoliberalism. And in comparison with other Latin American countries, it is a country with a strong historical legacy of social welfare. Care needs are acquiring the status of a specific public domain and since the 1990s have held a central place on the public agenda. It is described as an emblem of social public policy, sustained by academics, women's organizations, the National Women's Institute and international cooperation (Batthyány 2013). As already dealt with in other studies (Aguirre et al. 2014), the key to putting care on the Uruguayan public agenda was the close relationship between the production of sociological knowledge and the promotion and generation of public policies. The search for this link has marked the course of sociological gender production in the country, from the perspective of critical theory, which proposes that the ultimate goal of generating knowledge is social transformation.

\footnotetext{
${ }^{7}$ In the 1990s, compulsory schooling was established from the 5 years of age until the end of secondary school.
} 
The design of a Sistema Nacional Integrado Cuidado (Integrated National Care System-SNIC) is part of a broader process of social reforms that began in the country in 2005 and that include changes to the healthcare and social security systems, as well as tax reform (Batthyány 2015). The SNIC is designed to adapt to changes in demographics (birth rate, aging), families (sexual division of labour, care deficit) and the labour market (increase in female employment, decrease in female unemployment). The proposal is to formulate a system grounded on universal rights-based social reform policies, together with the creation of services that can support families with the hire of care both in and outside of the home. Territorial decentralisation is a core part of this system, seeking to generate 'local services' that are flexible enough to take into account the specific needs of each community for each service. Community participation, in new formats while taking advantage of existing ones, is a cornerstone from a rights perspective. Finally, it is also proposed that care work should be strengthened and professionalised through the training of both family and paid caregivers, with special consideration given to gender, generational and ethnic-racial mainstreaming. As for public centres, the goal is to universalise day care (minimum of 4 hours) for children between two and 3 years of age from poor and vulnerable households by means of Centros de Atención a la Infancia y la Familia (Childhood and Family Care Centres-CAIF).

These advances in the South American region are connected with the so-called 'Pink Tide', characterised by a period of major and intense political activity in the region. The state once again occupied a central role in redistribution and equity policies. Although the issue of sexual division of labour was not as central as gender violence $^{8}$ or the conquest of rights (reproductive rights in the case of Uruguay or $\mathrm{LGBTQI}^{9}$ ) this tide seemed to have had positive and promising implications for change to family and labour policies to improve equity. But the rise of neoliberalism changed those perspectives.

\subsection{Times of Feminist Troubles and Struggles in Growing Neo-Liberal and Authoritarian Environments}

The 1990s and 2000s have been characterised by relatively intense activity in terms of gender equality in a large number of European and Latin American countries. Attention has focused more on helping women to balance work and family life than on encouraging and forcing men to do reproductive work. But state feminism suggested the possibility of progressive change. Since the 2008 crisis in Europe and the

\footnotetext{
${ }^{8}$ For example, Brazil, after the vote on the Maria de Penha Law, became a benchmark for several countries regarding their legislative and legal progress in the fight against violence against women. ${ }^{9}$ Argentina (in 2012) and Uruguay (in 2009 and 2018) legislated on the 'trans issue' to bring about a change of civil status, promote demedicalisation and, in the case of Uruguay, access by trans people to education, culture, work and health.
} 
end of the 'Pink Tide' in Latin American countries, the situation has become more unstable and the potential for changing gender relations through the institutionalisation of feminism is less obvious. State feminism is turning into market feminism (Kantola 2012), which is characterised by the introduction of private actors to the promotion of gender equality, such as private employers that act to facilitate conciliation. The arrival in power of (sometimes ultra) conservative governments on both continents, and even of authoritarian and neo-fascist governments in the Brazilian case, has been accompanied by drastic budget cuts in terms of equality, to which we must add the emergence of an anti-feminist backlash that has generated new kinds of feminist struggles.

\subsubsection{The Recent Shift in Gender Equality Policies}

Anti-crisis measures have had a major gender impact, the scope of which has yet to be determined. However, in retrospect of a certain number of years of recession policies in Europe, new research has analysed the consequences of neoliberalism for emerging gender regimes. In the United Kingdom, it is known that the destabilisation of the public sector, severe tax restrictions and, in particular, the drop in social benefits and wages have hit mothers directly (Rubery and Karamessini 2013). Having children is still a key stage in the lives of women in the United Kingdom, which often marks a shift in career paths to part-time and low-paid jobs (Rubery and Karamessini 2013). Spain is also a very special case because it suffers highly from a vicious circle of budget cuts and structural reforms, supervised by the Troika (European Commission) (Salido Cortés 2020). Salido shows how gender inequalities have been one of the collateral effects of the crisis and austerity, relegating the feminist agenda to the background or even deleting it from political priorities. Lombardo (2017) identifies different indicators of feminist regression: (1) budget cuts on equality policies, (2) restructuring of equality institutions, (3) reduction of the Welfare State, (4) neoliberal employment policy, (5) stagnated representation of women, and (6) restriction of the right to abortion.

The new macroeconomic governance regime of the European Union has led, on all fronts, to poorer labour conditions for women. Adjustments in the public sector and the destruction of temporary employment have directly affected the quantity and quality of work by women of all social classes. In Spain, the reformed labour law (RD 3/2012) adopted in 2012 continues to impoverish labour conditions for everyone and women in particular. Many indirect gender effects have been observed, such as more flexible conditions for dismissal, the creation of new kinds of unstable jobs without the right to compensation in (highly feminised) companies with less than 50 female employees, the instability of part-time employment (where women are over-represented) and the indirect effects of this law on women. But the labour reform has also had direct consequences on the deterioration of employment for mothers: such as the limitation on the rights of breastfeeding workers or of mothers of young children who choose to work fewer hours; or the end of state financial 
incentives for companies that employ women returning from a long-term parental leave. In a context of low male involvement in domestic work, low income and economic constraints, there was a high risk of Spanish women being forced to withdraw to the domestic sphere (González and Segales 2014). In the name of austerity, the movement to foster women's rights has also been halted, such as the proposal to extend paternity leave, which will not be put back on the agenda for almost 10 years.

Spain seems to revise all the points. This is even bitterer when considering that the 2000s, especially during Zapatero's socialist government, were characterised by the institutionalisation and consolidation of feminist issues. But in other countries too, the reference to the 'austerity situation' and the need for 'rationing' are also used as arguments to justify budget cuts to women's rights organisations. Regarding care, it is interesting to note the French and Finnish cases. These two countries have been less directly hit by the European Troika and are viewed to be advanced in terms of the 'defamilialisation' of care and state (as opposed to paternal) participation, where the permanent rhetoric around the financial crisis also led to the reversion of state feminism. In France, the evolution of family policy is geared towards the development of individual services for families, to the detriment of the promotion of collective services, the same services that had moved France close to Sweden in this regard (Jarty 2006). Even so, nurseries are not only the most popular type of childcare for families (due to the professionalism of the staff and their contribution to learning about life in the community), but they are also the most effective way to guarantee social diversity (Delage 2018). This orientation forms part of the context of the absence of a full and complete ministry dedicated to women's rights (a campaign promise that President Macron failed to heed after his election in 2017) and a $27 \%$ reduction of the new Secretary of State's budget (Delage 2018).

In Finland, the election in 2015 of the conservative and populist right-wing government led to what has been deemed a triple political project, that of the "triangle of neoliberalism, conservatism and nationalism" (Elomäki and Kantola 2018). For these two sociologists, this new political turn considerably weakened state feminism, particularly through such significant cuts to public services and benefits that the very emblem of its women-friendly Welfare State, i.e. public care for all children by law, was dismantled. Following a new familialist line that defends "the families right to choose" their own kind of care, the state favours home care, which is much cheaper compared to the costs associated with childcare provided by the state or local councils (Kirsi and Kantola 2016). The introduction of New Public Management in the nineties, but with greater impact in the wake of the Great Recession in Europe, led to the inclusion of measures that involved the market and civil society, as well as the state. The transformation of the Nordic social model is also reflected in the introduction of economic and managerial rationality in the workplace: following on from programmes funded by the European Social Fund (ESF), companies are now addressing the issue of balancing work and family life (Kirsi and Kantola 2016).

While the last decade has been characterised by the weakness of the European Union and European governments to promote programmes for change in gender relations, in the Latin American case, and particularly in the Southern Cone, there 
has also been gradual reversion of its progressive wave. This was first confirmed with the defeat of Kirchnerism in the Argentinian presidential elections of November 2015. From a feminist perspective, the new administration, with neoliberal businessman Mauricio Macri as president, was characterised by the absence of feminist issues on the political agenda and, at the end of his term, the denial of abortion after months of intense demonstrations. Then Brazil experienced an institutional coup against Dilma Roussef in 2016 and, 2 years later, the election of former far-right military leader Jair Bolsonaro (October 2018), a nightmare for the feminist and LGBTQI movement. Before that, Chile witnessed the victory of billionaire businessman Sebastián Piñera (March 2018). And in November 2019, the election in Uruguay of the Catholic, liberal, conservative Luis Lacalle Pou also put years of progressivism and collaboration with the feminist movement at risk. In reaction to this phase in which feminist issues were fading from the political agenda (with different intensity depending on the context), the South America started building a new laboratory for feminism.

\subsubsection{Institutional Failures and (South American) Street Feminism Riposte}

Faced with defections and instabilities of European governments in terms of promoting equality, the European directive on parental leave shows how hard it was for the European Union to recover its gender equality friendly image. In a context of the EU's alliance with the IMF and the financial markets and, more generally, its active participation in sometimes drastic budget cuts that affected the living conditions of a significant part of the population, this was an attempt by the institution to reactivate and showcase its 'social base' (Collombet and Math 2019). In line with the measures to "facilitate the reconciliation of work and family life" that started in the late 1990s, the draft revision of the 2018 European directive on parental leave echoes an old and important feminist demand: the shared distribution of domestic work between women and men. The first version of the project is ambitious and proposes a reformed directive, based on the following principles: (1) the introduction of the principle of payment for parental leave, at least up to the same level of pay that the worker would receive as sick leave; (2) the introduction of the principle of non-transferable parental leave between parents; (3) the possibility of exercising this right until the child turns 12 years of age; (4) the introduction of paternity leave or second parent leave (depending on whether or not Member States recognise same-sex parenting) paid at $80 \%$ of salary and without seniority conditions; (5) the introduction of a right for parents to request different working hours; (6) implementation of a 5-day leave for caregivers of dependent persons.

So, for the first time, the feminist goal of sharing domestic work and care is explicitly at the centre of a draft European directive. Until now, many researchers had advocated co-opting (or even exploiting) the feminist goals of a more equal 
distribution of unpaid reproductive work through targets focused on economic and demographic growth (Knijn and Smit 2009; León 2009; Stratigaki 2004). So, all the measures promoted by the European Union aimed at facilitating "the reconciliation of work and family life" had focused only on women/mothers and, in doing so, their results did absolutely nothing to change the sexist nature of social structures. During the debates on the reform of the directive on parental leave, the proposed measures were specifically inspired by the Nordic equality systems that had been so highly praised until then (Stratigaki 2004) but that had never received specific instruments.

But the tensions and disagreements between the Council of Europe, which opposed a measure it viewed as too costly and a violation of the principle of subsidiarity, and the European Parliament, to reinforce social welfare and rights regarding access to parental leave, have given rise to a minimalist version of the project. As in 2008, when it blocked the reform of the 1992 directive on paid maternity leave, France (supported at the time by Germany, the Netherlands and Poland) contributed significantly to the adoption of an impoverished version in terms of women's rights: President Emmanuel Macron has publicly described the "potentially exorbitant costs" of this measure. Ultimately, the agreement continued after controversial negotiations at tripartite meetings. This trialogue was criticised for its lack of transparency and informality, and reflected the limited vision of the Council of Europe: (1) the number of non-transferable months increased from one to 2 months; (2) the obligatory nature of paid parental leave was limited to a period of one and a half months and its amount was left to the discretion of the Member States; (3) the maintenance of the age limit for children was left to the discretion of the Member States and could go up to the child's eighth birthday; (4) the introduction of a two-week leave reserved for fathers or 'second parents' (if such a statute exists in national legislation), but subject to 6 months' seniority; (5) the introduction of a right to 5 days of leave for caregivers in cases of serious illness or dependency on a close relative; (6) the right to request flexible working hours to facilitate balance between work and family (distance work, part-time work or flexitime) for caregivers and fathers up to a maximum age of the child that cannot be less than 8 years of age.

Therefore, very few countries needed to change the existing framework: Italy (with Greece, Hungary, Luxembourg, the Netherlands and Romania) needed to open or extend leave for fathers or second parents to 15 days. Spain (with Cyprus, Greece, Malta, Ireland and the Netherlands) needs to provide for parental leave. Only Spain took the opportunity to take the proposal much further ${ }^{10}$.

\footnotetext{
${ }^{10}$ On 4 April 2018, Parliament adopted the principle of replacing maternity and paternity leave with $100 \%$ paid maternity leave (below a maximum limit), for a period of 16 weeks that is nontransferable for both parents, including six mandatory weeks for the biological mother and father (or the mother's partner in the case of lesbian couples) after birth. The remainder may be taken, even sporadically, up to the child's first birthday. The reform is being implemented quickly: parental leave, which had already been increased from 2 to 5 weeks in the summer of 2018, rose to 8 weeks on 1 April 2019 (including two mandatory weeks after birth), then to 12 in 2020 and 16 in 2021.
} 
This backlash, which considerably weakened European state feminism, was followed by the clear reversal of the progressive tide in South America in parallel with a rise in autonomous feminist movements. We have briefly seen that in the context of transitions (in the 1980s and 1990s) and democratic consolidation (in the 1990s and 2000s), the relationship between feminist movements and South American states gradually became one of negotiation and cooperation. Today, this relationship seems reversible: current more hard-line (and authoritarian in the cases of Chile and Brazil) neoliberalism has led to the resurgence of a mood of protest, which resonates internationally towards Europe. In addition to the views that South America has been a 'laboratory of neoliberalism' (in the case of Pinochet's Chile) or more recently as a 'laboratory of authoritarian liberalism' (in the case of Bolsonaro's Brazil), there is now the view that it is a 'laboratory of contemporary feminism'. New feminist issues are arising on the streets, with major consequences for the recomposition of the European feminist movements hit by the effects of 2008. And what are not really new feminist theories and concepts produced by Latin feminists are becoming apparent in academia. These do not deal with the issue of the sexual division of labour and care (although they did not exclude it), but concentrated first on the latest expressions of a power continuum: gender violence and more specifically femicide. Some of them have resonated internationally in the \#MeToo context, included in European INCASI project countries: the cry of Ni Una Menos ('Not one less') that became a hashtag, led to international demonstrations that spread from Argentina to the rest of America and Europe, especially in Spain, but also in Italy (with the cry Non Una Di Meno). Ni Una Menos was also a step towards other movements that in turn had resonated internationally: abortion in Argentina (with the hashtag \#NosotrasDecidimos, 'We decide') as well a sexual harassment (with the hashtag \#MiraComoNosPonemos, 'Look how hard we get' ${ }^{11}$ ).

Though focused first on gender violence, the demands extended to other issues, including the sexual division of labour. Making March 8 into a day of feminist striking illustrates both this phenomenon of extension throughout the entire power continuum, as well as the international circulation of feminist modes of action being autonomised by the state. Using the hashtag \#NosotrasParamos ('We stop') and exploiting the increasing number of internet platforms, marches were organised on both continents with common demands: equal pay, the end of the 'glass ceiling' and better laws on reconciliation between maternity and employment. The 2018 feminist strike and more especially that of 2019 were a success in several countries, especially in Argentina and Spain, thanks to a new social recognition of the feminist movement and the expansion of feminist networks of different groups. The manifesto of the Economía Femini(s)ta (EF) organisation, created in Buenos Aires in 2015, sums up the new inclusion of the sexual division of labour within a long power continuum in contemporary feminist movements: "We are striking for an end to sexist violence, lesbophobia, transphobia and all forms of gender-based

\footnotetext{
${ }^{11}$ Created after a public claim for abuse and rape was made by the Argentine actress Thelma Fardin against the actor Juan Darthés.
} 
exploitation. We are striking because we earn less than men for the same work and because unpaid domestic and care work is made our duty and affects our chances to study, work, and enjoy free time. We are striking because we are the majority of the world's poor, and the majority of workers with the most unstable and worst paid jobs. We are striking because we are undervalued in work environments, objectified and sexually harassed in public and private spaces" ${ }^{12}$. Another prominent case was the international resonance of the Un Violador en tu Camino ('A rapist in your path') performance piece by the Chilean LASTESIS group ${ }^{13}$, put on for the first time to denounce the sexual abuse by the police during the Chilean social uprising of late 2019. It confirmed both the conflictive relationship between popular feminist movements and the state, and the need not to separate or hierarchize feminist struggles (in this case against neoliberalism and gender-based violence).

The south-north circulation of new demands has gone hand in hand with the exchange of new theories and concepts. Southern feminism, or Feminismo a la contra ('counter feminism') (Martínez Andrade 2019), has led to new social approaches and connections with the streets. Ni Una Menos was a step towards the south-north (South America-Europe) circulation of concepts: that of femicide, for example. The international resonance of the outrage and demonstration after the assassination of Marielle Franco in Rio de Janeiro sparked the movement to spread decolonial ideas. This theoretical tradition is also characterised by a critique of a hegemonic white feminism, blind to race, but also very urban, and has paved the way for new feminisms grounded on indigenous, African-American and lesbian demands. This has engendered other analytical frameworks in which to design social models for change and inclusion.

\subsection{Conclusions}

We have a lot to learn from a comparison between Europe and Latin America. The contrast provides an overview of our social systems, their implications for how gender relations are organised, and an understanding of how they work in each country. On both sides of the Atlantic, though more highly prevalent in Europe, in the context of European institutionalisation of feminism in the 1990s, care emerged as an important issue in both the institutional and academic feminist spheres. It led to a series of academic studies, as well as national and international policy programmes on the matter of 'reconciliation'. These policies led countries to be positioned in a typology of 'gender contracts', mostly established according to the level of deinstitutionalisation of the Male Breadwinner model. The construction of academic typologies in terms of care regimes was viewed as an important comparative

\footnotetext{
${ }^{12} \mathrm{https} / / /$ economiafeminita.com/nosotras-paramos/

${ }^{13}$ Using a precise choreography, the text is taken from feminist literature, especially that of Argentinian anthropologist Rita Segato.
} 
indicator of the advances in gender equality between countries. But today, after several economic crises and the rapid rise of neoliberalism, how much of this interpretation still holds? How and why is it mobilised in a new context?

From the point of view of undertaking a comparative research study between Europe and Latin America that takes into account gender mainstreaming, these typologies are a starting point to decipher the state of gender relations in countries where gender issues are approached differently. It can compare the importance given to the transformation (or not) of the sexual division of labour, whether by the feminist movement or by institutions, in the countries of the two continents. But above all, the integration of Latin American contributions to European analyses means we can revise the analytical framework and adapt it to a new social reality. This is especially the case with regard to the introduction of the issue of social equality in a context of multiple crises of capitalism.

Indeed, the increased participation of women in the labour market and the decline of the Male Breadwinner model are largely confirmed in the countries studied. Women are reluctant to go back into the home, although they continue to hold primary responsibility for day-to-day domestic work. The risk of women being 'redomesticated' (Lombardo 2017), either because right-wing populist, exclusionary and totalitarian systems, or neoliberal projects, the primary allies of the financial world, is not happening, not even in the countries that are most affected by the Great Recession in Europe (like Spain) or authoritarianism (like Brazil). Women are staying in the labour market, but the labour market has deteriorated considerably, bringing the new European divides a little closer to the structural ones in Latin America (or, at least, making Latin American contributions to and knowledge of social inequalities increasingly more relevant). Salaried employment, a source of social welfare, is increasingly more segmented, characterised by a social divide between women. On the one hand, privileged women (with degrees, white, urban, often with a "powerful" passport) have more and more opportunities to enjoy the advances of the wage society and economic power. But this opportunity and these privileges have led to few structural changes in terms of gender. On the other hand, a growing proportion of women in Europe are not getting the long-awaited social protection afforded by wealthy societies. Non-academically qualified, racialised, rural, migrant women experience this divide most intensely. The on-going rise of the 'neoliberalconservative-nationalist' triangle in European countries (Elomäki and Kantola 2018), which would be interesting to compare in Latin American countries, is specifically jeopardising the rights and living conditions acquired thus far by women, and especially the least privileged ones.

\section{References}

Aguirre, R. (2008). El futuro del cuidado. In I. Arriagada (Ed.), Futuro de las familias y desafíos para las políticas, Serie Seminarios y conferencias 52. CEPAL: Santiago de Chile.

Aguirre, R., Batthyány, K., Genta, N., \& Perrotta, V. (2014). Los cuidados en la agenda de investigación y en las políticas públicas en Uruguay, Íconos. Revista de Ciencias Sociales, 50, 43-60 
Batthyány, K. (2013). Perspectivas actuales y desafíos del Sistema de Cuidados en Uruguay. In L. Pautassi \& C. Zibecchi (Eds.), Las fronteras del cuidado. Agenda, derechos e infrastructura (pp. 385-400). Buenos Aires: Ed Biblos.

Batthyány, K. (2015). Las políticas y el cuidado en América Latina: una mirada a las experiencias regionales. Santiago de Chile: Naciones Unidas.

Blofield, M., \& Martínez Franzoni, J. (2015). Maternalism, co-responsibility and social equity: A typology of work-family policies. Social Politics, 22(1), 38-59.

Collombet, C., \& Math, A. (2019). La nouvelle directive «équilibre » sur les congés parentaux, de paternité et d'aidant: une avancée de l'Europe sociale ? Chronique Internationale de l'IRES, $166(2), 3-15$.

Crompton, R. (1999a). Employment and the family. The reconfiguration of work and family life in contemporary societies: Cambridge University Press.

Crompton, R. (1999b). Restructuring gender relations and employment: The decline of the male breadwinner. Oxford: Oxford University Press.

Dauphin, S. (2010). L'État et les droits des femmes. In Des institutions au service de l'égalité ? Rennes: Presses Universitaires de.

Delage, P. (2018). Droits des femmes, tout peut disparaître. Paris: Textuel.

Elomäki, A., \& Kantola, J. (2018). Theorizing feminist struggles in the triangle of neoliberalism, conservatism, and nationalism. Social Politics: International Studies in Gender, State \& Society, 25(3), 337-360.

Fagnani, J. (2007). Fertility rates and mothers' employment behaviour in comparative perspective: Similarities and differences in six European countries. In R. Crompton, S. Lewis, \& C. Lyonnette (Eds.), Women, men, work and family in Europe (pp. 87-113). London: Palgrave Macmillan.

Faludi, S. (1991). Backlash: The undeclared war against American women. New York: Crown.

Faur, E. (2014). El cuidado infantil en el siglo XXI, mujeres malabaristas en una sociedad desigual. Buenos Aires: Siglo Veintiuno Editores.

Filgueira, F. (1998). El Nuevo Modelo de Prestaciones Sociales en América Latina: Residualismo, Eficiencia y Ciudadanía Estratificada. In B. Roberts (Ed.), Ciudadanía y Políticas Sociales (32-73). Costa Rica: San José.

Fraser, N. (1997). Justice Interruptus? Critical reflections on the 'Postsocialist' condition. New York and London: Routledge.

Fraser, N. (2013). Feminism, capitalism and the cunning of history. In N. Fraser (Ed.), Fortunes of feminism: From state-managed capitalism to neoliberal crisis (pp. 209-227). London: Verso.

Goldin, C. (2006). The quiet revolution that transformed Women's employment, education, and family. NBER Working Paper, 11953, 1-49.

Gonzalez Gago, E., \& Segales Kirzner, M. (2014). Women, gender equality and the economic crisis in Spain. In M. Karamessini \& J. Rubery (Eds.), Women and Austerity: The Economic Crisis and the Future for Gender Equality (228-270). Abingdon: Routledge.

Hill Collins, P. (1990, 2000). Black feminist thought: Knowledge, consciousness and the politics of empowerment. New-York: Routledge.

Jarty, J. (2006). Interface travail-famille et inégalités de sexe: Regards croisés sur les effets de l'action publique en Espagne et en France. In Acte de la journée d'étude: Les études genre à l'UTM. Approches pluridisciplinaires, Toulouse, Mission égalité Femmes Hommes, Université de Toulouse-Le Mirail et Artemisia.

Kantola, J. (2012). From state feminism to market feminism? International Political Science Review, 33(4), 382-400.

Kirsi, E., \& Kantola, J. (2016). The Europeanization of Nordic gender equality: A Foucauldian analysis of reconciling work and family in Finland. Gender, Work and Organization, 23(4), 414-430.

Knijn, T., \& Smit, A. (2009). Investing, facilitating, or individualizing the reconciliation of work and family life: Three paradigms and ambivalent policies. Social Politics, 16(4), 484-518.

Korpi, W. (2000). Face of inequality. Social Potitics, 7(2), 127-191. 
Le Feuvre, N. (2018). Conclusion: Reconfigurations des enjeux de l'égalité dans les sociétés contemporaines. In M. Maruani (Ed.), Je travaille, donc je suis: Perspectives féministes (pp. 267-277). Paris: La Découverte.

León, M. (2009). Gender equality and the European employment strategy: The work/family balance debate. Social Policy and Society, 8(2), 197-209.

Lewis, J. (1992). Gender and the development of welfare regimes. Journal of European Social Policy, 2(3), 159-173.

Lombardo, E. (2017). The Spanish gender regime in the EU context: Changes and struggles in times of austerity. Gender, Work and Organization, 24(1), 20-33.

Lombardo, E., \& Del Giorgio, E. (2013). EU antidiscrimination policy and its unintended domestic consequences: The institutionalization of multiple equalities in Italy. Women's Studies International Forum, 39, 12-21.

Lombardo, E., \& Sangiuliano, M. (2009). Gender and employment in the Italian policy debates 1995-2007: The construction of 'non employed' gendered subjects. Women's Studies International Forum, 32(6), 445-452.

Magalhaes, M. J., \& San Romanelli, A. (2017). Can feminism belong to the state? Reflections on state feminism and feminist institutionalism. In Congreso Fazendo Gênero 11. Federal: University of Santa Catarina (UFSC).

Manrique, P. (2019). Prólogo: La tercera ola revolucionaria de/contra la Modernidad. In L. Martínez Andrade (Ed.), Feminismos a la contra, Entre-vistas al Sur Global (pp. 13-28). Santander: La Vorágine.

Martínez Andrade, L. (2019). Feminismos a la contra, Entre-vistas al Sur Global. Santander: La Vorágine.

Martínez Franzoni, J. (2008a). Bienestar y regímenes de bienestar, ¿qué son y porqué abordarlos? In J. Martínez Franzoni (Ed.), ¿Arañando bienestar? Trabajo remunerado, protección social y familias en America Central (pp. 23-54). Buenos Aires: CLACSO.

Martínez Franzoni, J. (2008b). Welfare regimes in latin America: capturing constellations of markets, families, and policies. Latin American Politics and Society, 50(02), 67-100.

Mendoza, B. (2014). Ensayos de crítica feminista en Nuestra América. México: Herder.

Nari, M. (2004). Politicas de maternidad y maternalismo politico. Buenos Aires: Biblos.

Navarro, S. (2004). Redes sociales y construcción comunitaria. Madrid: CCS.

Oinonen, E. \& Tervonen-Gonçalves L. (2019). Comparing, categorizing and constituting welfare states, communication at congreso de la FES, July 3rd, 2019.. Valencia.

Orloff, A. S. (1996). Gendering the comparative analysis of welfare states: An unfinished agenda. Sociological Theory, 27(3), 317-343.

Orloff, A. S. (2009). Gender in the welfare state. Annual Review of Sociology, 22, 51-78.

Pateman, C. (1988). The patriarchal welfare state. In A. Gutmann (Ed.), Democracy and the welfare state (pp. 231-278). NJ: Princeton University Press.

Pfau-Effinger, B. (2004). Socio-historical paths of the male breadwinner mode-An explanation of cross-national differences. British Journal of Sociology, 55(3), 37-200.

Rubery, J., \& Karamessini, M. (2013). Economic crisis and austerity: Chanllenges to gender equality. In J. Rubery \& M. Karamessini (Eds.), Women and austerity: The economic crisis and the future for gender equality (pp. 314-352). Abingdon: Routledge.

Salido Cortés, O. (2011). Female employment and policies for balancing work and family life in Spain. In A. M. Guillen \& M. Leon (Eds.), The Spanish welfare state in European context (pp. 187-208). Farnham: Ashgate.

Salido Cortés, O. (2020). L'impact de genre de la crise en Espagne et au Portugal. In A. Fernández (Ed.), L'Espagne et le Portugal après la crise: mutations sociales et défis politiques. Forthcomming: Presses Universitaires de Rennes.

Sarasa, S. (2011). Long-term care: The persistence of familism. In A. M. Guillen \& M. Leon (Eds.), The spanish welfare state in european context (pp. 237-258). Ashgate: Farnha.

Segnana, M.-L., \& Vila, P. (2015). Women and austerity in Italy. Ex aeco, 32, 15-32. 
Sorj, B., \& Fontes, A. (2009). Les politiques publiques au Brésil et l'articulation entre travail et famille. Une comparaison interrégionale, Cahiers du Genre, 46(1), 155-176.

Stratigaki, M. (2004). The cooptation of gender concepts in EU policies: The case of 'reconciliation of work andfamily'. Social Politics, 11(1), 30-56.

Sunkel, G. (2007). El papel de la familia en la protección social en América Latina. In J. Astelarra (Ed.), Género y cohesión social. Madrid: Fundación Carolina.

Torns, T., Carrasquer, P., Moreno, S., \& Borras, V. (2013). Career paths in Spain: Gendered division of labour and informal employment. Revue Interventions économiques, 47, 1-14.

Walby, S. (2009). Globalization and inequalities: Complexity and contested modernities. London: Sage.

Open Access This chapter is licensed under the terms of the Creative Commons Attribution 4.0 International License (http://creativecommons.org/licenses/by/4.0/), which permits use, sharing, adaptation, distribution and reproduction in any medium or format, as long as you give appropriate credit to the original author(s) and the source, provide a link to the Creative Commons licence and indicate if changes were made.

The images or other third party material in this chapter are included in the chapter's Creative Commons licence, unless indicated otherwise in a credit line to the material. If material is not included in the chapter's Creative Commons licence and your intended use is not permitted by statutory regulation or exceeds the permitted use, you will need to obtain permission directly from the copyright holder. 